\title{
CHALLENGES AND DILEMMAS OF CONTROLLING IN THE REPUBLIC OF SERBIA
}

\author{
Veselin Perović, \\ Ranko Bojanić1, \\ Aleksandra Todorović-Dudić2
}

'University of Novi Sad, Faculty of Technical Sciences, Novi Sad, Serbia

2University Business Academy, Faculty of Economics and Engineering,

Novi Sad, Serbia

\begin{abstract}
:
Controlling represents a modern philosophy and business function, an expert support to management. It contributes to transparency, as well as to the coordination and integration of business operations. Many studies have been conducted worldwide dealing with controlling, while such studies have not yet been undertaken in the Republic of Serbia. This paper examines the reality of controlling in Serbian companies. In our theory and practice little is known about controlling as a modern instrument, which is necessary for making the business successful. The aim of this paper is to present the situation on the basis of empirical research carried out in manufacturing and service companies in Serbia, as well as the dilemmas and challenges of successful implementation of controlling in business practice in the Republic of Serbia. The conclusion of this paper is that the usefulness of controlling is recognized in the Republic of Serbia and that the degree of acceptability of controlling is constantly increasing.
\end{abstract}

\section{Keywords:}

controlling, public sector, non-profit organizations.

\section{INTRODUCTION}

The claim that controlling is nothing more than planning and analysis is often heard in Serbia, and in organizational schemes of Serbian companies controlling has mainly been linked to this department. One of the important tasks of controlling is certainly planning and analysis. ${ }^{1}$ However, the scope of controlling is much wider than that and includes all functions in the company which uses controlling as a performance measuring instrument. ${ }^{2}$ Therefore, it can be said that only one aspect of controlling has been demonstrated in Serbia - planning, and analysis. Enterprises in Serbia began to introduce controlling in the 1990s. At that time, controlling was introduced only in subsidiaries of foreign companies.

The form of presence of controlling in the organizational structure (i.e. within the finance and accounting department or as an independent function) mostly depended on the size of the enterprise. However, regardless of the place it was located, controlling often covered only tasks from areas of accounting, finances, or internal audit, which unlikely belongs within its scope. Since no formal education was available for controllers in Serbia, or it is still missing, controlling experts were unable to obtain education. Today, there are few faculties in Serbia where controlling is being studied as a scientific discipline, among which the Faculty of Technical Sciences is the most distinguished, ${ }^{3}$ where controlling has been studied for 12 years at undergraduate and specialized vocational studies, in which students are being trained in controlling tasks, studying several subjects related to controlling.

1 Horávth, P. (2009). Das Controlling konzept, Stuttgard. Weber, J., Schäffer, U. (2008). Einführung in das Controlling. Stuttgard.

2 Todorović-Dudić, A., Stanišić, M., Perović, V. (2017). Contribution of Controlling to business efficiency. Industrija, 45 (1), pp. 22 - 44.

e-mail:

vesa@uns.ac.rs
3 Perović, V., Vujičić, M. (2015). Controlling: between theory and practice. International Journal of Industrial Engineering and Management - IJIEM, 2015. 6 (4), pp. 165-170. 


\section{RESEARCH PROBLEM}

So, how was the controller knowledge transferred in Serbia? By working in foreign companies that transferred the controlling function to their branches in Serbia, controllers also had the opportunity to acquire knowledge and skills in the field of controlling which they subsequently passed on to other Serbian companies. On this path of "oral transmission", a considerable confusion arose in understanding what controlling really is and how it works. The first steps in controlling in Serbia were taken by companies such as Hemofarm, whose majority owner became the German Stada, followed by companies like Somboled, NIS, Lafarge, which are also owned by foreign companies. However, this method of introduction of controlling into Serbian economy had some problems. One of the common mistakes was treating controlling exclusively as a reporting function. The reason for this can be again found in practice - foreign companies often send a number of ready-made report forms to domestic controllers to be filled out with information from the company's information system. It may result in a misconception that preparing business reports is the sole task of controlling. In fact, business reporting is just a small segment of the overall controlling job that comes as a "cream on the cake". Furthermore, controlling is often equated with the function of finance and accounting, and accordingly, it is assigned to financial-accounting jobs, which is completely wrong. Below is a list of some of the characteristics of Serbian "newly established" companies that need to introduce and develop controlling:

- Unified ownership and management function

- Autocratic decision-making - centralized decisionmaking

- Not involving employees in the formation of organizational structure

- Poor personnel policy or lack of any personnel policy

- Lack of quality communication

- Traditional accounting focused primarily on external reporting

- Information system that fails to support modern management

- Lack of permanent employee education (training)

- Ineffective internal processes

- Large indebtedness and poor collectability

- Very low levels of employee motivation.

All of the above indicates the necessity of introducing controlling in response to problems of coordination and integration of managerial subsystems. The next part of the paper presents the results of research on the state of controlling in the Republic of Serbia.

4 Bojanić, R., (2012). Kontroling u Srbiji - utopija ili realnost. II konferencija kontroling i interna revizija, Novi Sad, 30-31.12.2012 godine, str. $12-15$.

5 Osmanagić Bedenik, N. (2007). Realnost kontrolinga u Hrvatskojrezultati empirijskog istraživanja. Zbornik Ekonomskog fakulteta u Zagrebu, god. 5, broj 1, Zagreb.

\section{Research methodology and sample}

Selecting a sample represents a specific problem in scientific research. ${ }^{5}$ The goals of this research were focused on companies that already have or are in the phase of introducing controlling into their organizational structure. ${ }^{6}$ Namely, studies conducted in the European area have shown that large and medium-sized organizations, as well as subsidiaries of large foreign organizations, generally have controlling implemented in institutional terms, and this research was directed towards similar enterprises operating in the Republic of Serbia. It is important to note that controlling is a function, a content, whose implementation in an organizational form is optional, and the purpose of this research was to identify organizations that have controlling implemented in organizational, institutional sense. In this research, the sample was selected based on the register of medium-sized and large enterprises, bearing in mind that we tried to examine the state of controlling in the business practice of companies with the largest turnover, as well as renowned companies.

A sample of 180 organizations was compiled and questionnaires were dispatched to their addresses. As a response, a total of 87 completed survey sheets were received (a 48.3\% return rate), and based on these data, the sample can be considered reliable. Given the limited space, the obtained data were analyzed using mainly quantitative methods, while the results obtained by quantitative and qualitative analysis will be presented in the next paper.

\section{DISCUSSION}

The next part of the paper presents the results of the empirical research conducted in the Republic of Serbia over the period from October to December 2015. ${ }^{7}$ The questionnaire was sent to 180 companies, and by the end of December, 87 completed survey questionnaires were received, or $48.3 \%$ (which makes the research relevant in the academic framework). The analysis will shed some light on the institutional framework of organizational aspects and offer directions for further research on controlling Serbia. The first part of the questionnaire was devoted to the organizational structure of companies depending on their activities, and whose presence in the sample is shown in Chart 1. Based on the analysis, it can be seen that the majority of respondents (42) belong to manufacturing organizations, and 29 of them to service companies. However, the rest of responses came from

6 Perović, V., Osmanagić-Bedenik, N., Bojanić, R., Todorović-Dudić, A. (2016). Recent Situation of Controlling in Serbia and Comparison with its Implementation in Croatia. Revizor, 2016, No 76/2016, pp. 29 - 39.

7 Perović, V., Bojanić, R. (2016). Osnove kontrolinga. Univerzitet u Novom Sadu - Fakultet tehničkih nauka, Novi Sad str. 31 - 38. Perović, V. (2016). Uloga i značaj primene kontrolinga u poslovnoj praksi. Računovodstvo, Časopis za računovodstvo, reviziju i poslovne finansije, God. LX, Br. 1-2016, str. 168 - 183. 
service companies or trading companies, but users have specified the activity they pursue. Trading companies 7 $(8 \%)$ were separated from service providers to obtain a more realistic analysis of the state of controlling in the Republic of Serbia.

Chart 1. Structure of activities of the analyzed companies

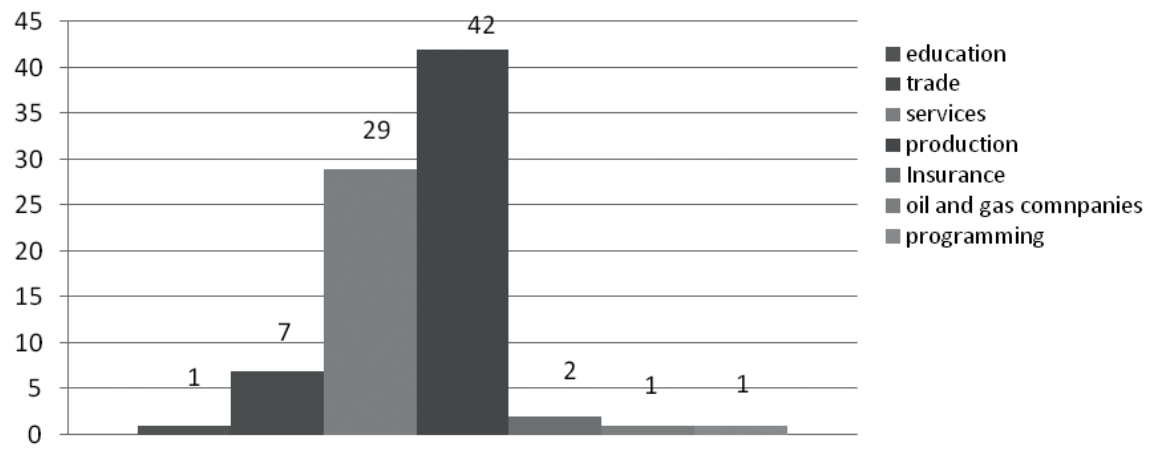

Source: Authors research ${ }^{8}$

Empirical studies conducted in well-developed market economies have shown that the company size is one of the determining factors of institutional aspect of controlling, and therefore, part of the research was dedicated to this variable. According to the number of employees, companies with over 250 employees, or 57 respondents (65.5\%), were the most represented in the sample, followed by companies from 50 to 250 employees with 16 respondents (18.4\%), and those with up to 50 employees, which were represented by 14 respondents (Chart 2).

Chart 2. Structure of enterprise size depending on the number of employees

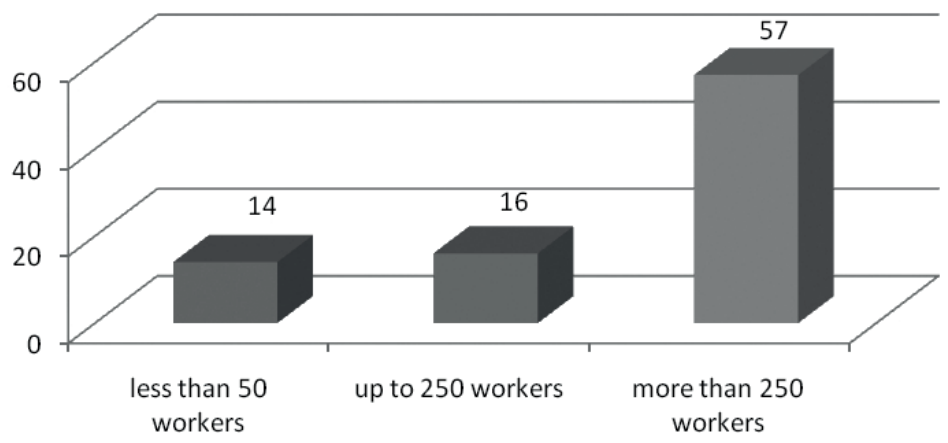

After questions about activity, size and other imporfocused on the presence of controlling in the institutional tant elements identifying the companies, the research was sense. The answers are presented in Chart 3.

Chart 3. Presence of controlling in institutional form 
The results have shown that controlling was represented in the organizational structure of $32 \%$ of enterprises covered by the research, while $68 \%$ of the enterprises lack controlling in any organizational form. The results, however, were encouraging and proved that controlling is slowly gaining importance in Serbian business environment. It should also be noted that the research was focused more on the functioning of controlling in the Republic of Serbia than on the number of companies that implemented controlling in their organizational structure.
After analyzing the number of companies that have controlling implemented in their business, the focus was shifted on the percentage of companies that use external controlling services, and the data indicated that $31 \%$ of companies that participated in the survey were using these services. Based on this analysis, it can be assumed that companies lacking controlling use external controlling services (Chart 4).

Chart 4. The number of companies using services of external controlling (\%)

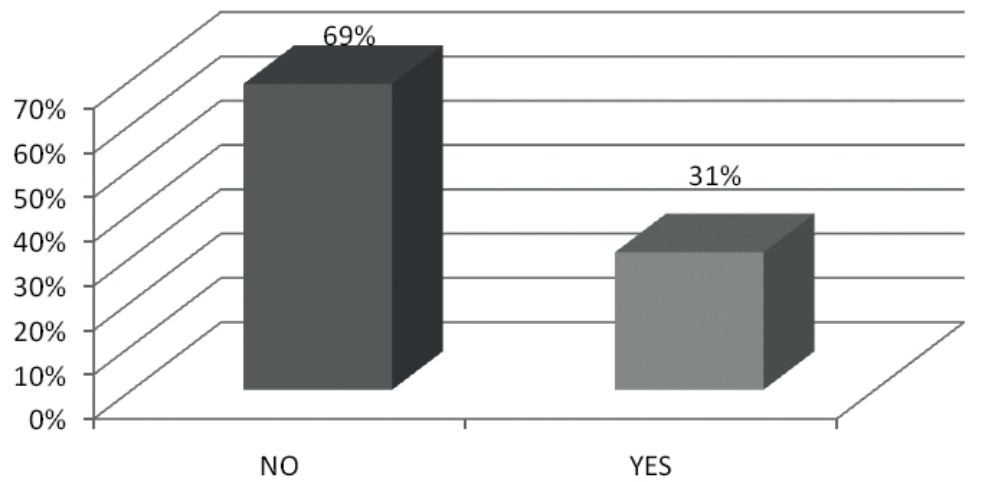

Considering the presence of controlling in companies in the Republic of Serbia, the question arises about who should encourage the introduction of controlling in the highest possible number of companies? How to improve the state of controlling in Serbia and increase the number of companies that have a controlling department?

Chart 5. Number of employees in controlling

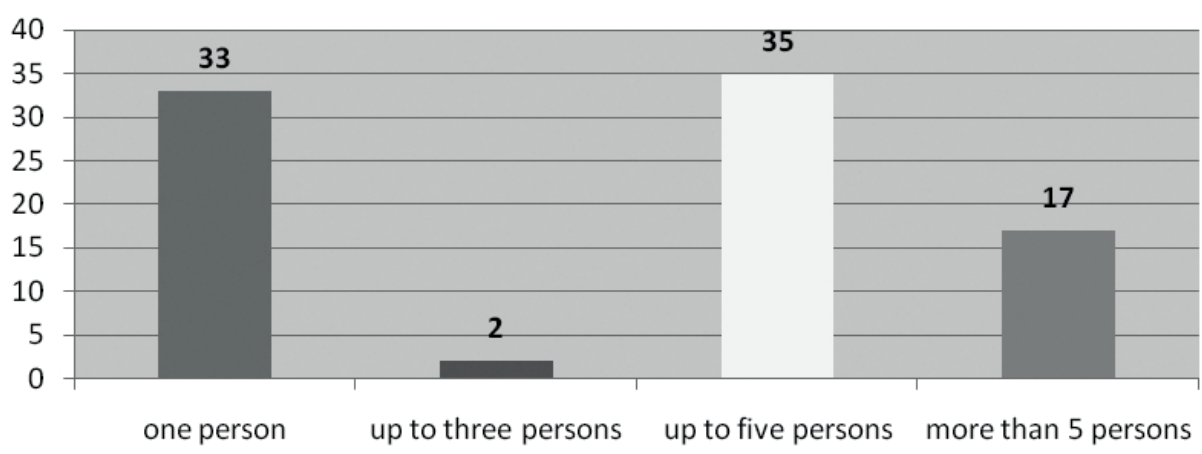

In the analysis of research regarding the number of employees working in controlling, the core of the problem in the Republic of Serbia has been revealed. It was stated that most companies in foreign ownership having implemented controlling and they initiated controlling at our market, but in these companies (dependent) controlling primarily serves as a reporting tool for the top management, and hardly helps to the management of the local company. This can be seen in Chart 5, 33 companies employ 1 person in the controlling department, 2 to 3 persons are employed by 2 companies, while 35 companies employ 3 to 5 persons. 17 analyzed enterprises employ more than 5 employees. The number of controllers in the observed companies is unsatisfactory. The question is, why is it so? Is there a lack of professional staff? Is the role of controlling in these companies only reporting? Do these companies fail to recognize the importance of controlling for business success? The answer to these questions lies in the fact that there is a very small number of faculties and universities where controlling is being studied as an academic discipline, and there is a lack of qualified controllers 
at the Serbian market. However, foreign companies in their subsidiaries have introduced controlling in the form of reporting, while other controlling tasks are taking place at the headquarters. Many companies still mistake controlling for planning and analysis and believe that controlling cannot contribute to the successful operation.

Chart 6. Contribution of controlling to the success of the enterprise in $\%$

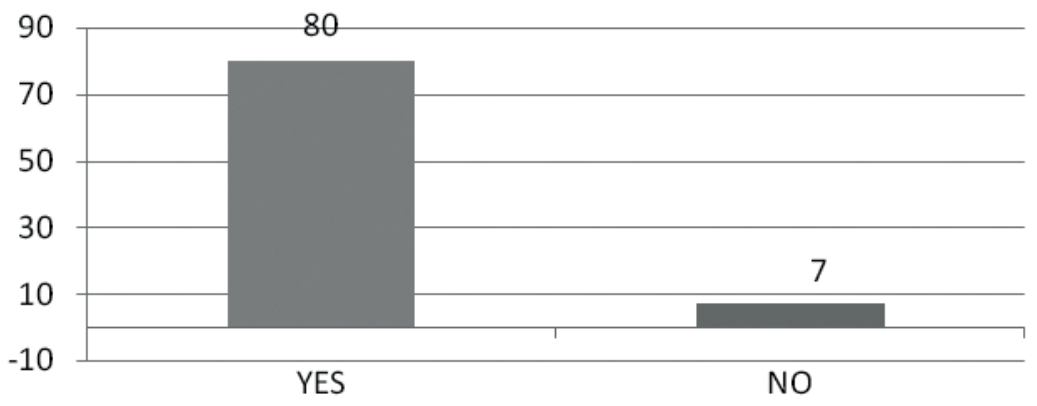

The most important part of this research was focused on the opinion of respondents on the importance of controlling for the successful operation of their company (Chart 6). The research was divided into five groups as follows:

- Controlling is the most important source of information

- Controlling is the place of planning and business analysis

- Controlling is a consultant for business decisions

- Controlling is a coordinator and integrator of business functions

- The role of controlling is irrelevant
The respondents were asked to evaluate the role of controlling through each of these questions on a scale from 1 to 5 , with 1 being the lowest and 5 the highest score.

\section{Controlling is the most important source of information}

By analyzing the data obtained from this research it can be seen that the largest number of respondents, as much as $50(57.5 \%)$ answered that controlling is the most important source of information for successful operation. It can be seen (Chart 7) that none of the respondents has rated this factor with 1 and 2, which indicates that most respondents in these companies take controlling seriously as the source of information in performing their jobs.

Chart 7. Controlling as the most important source of information

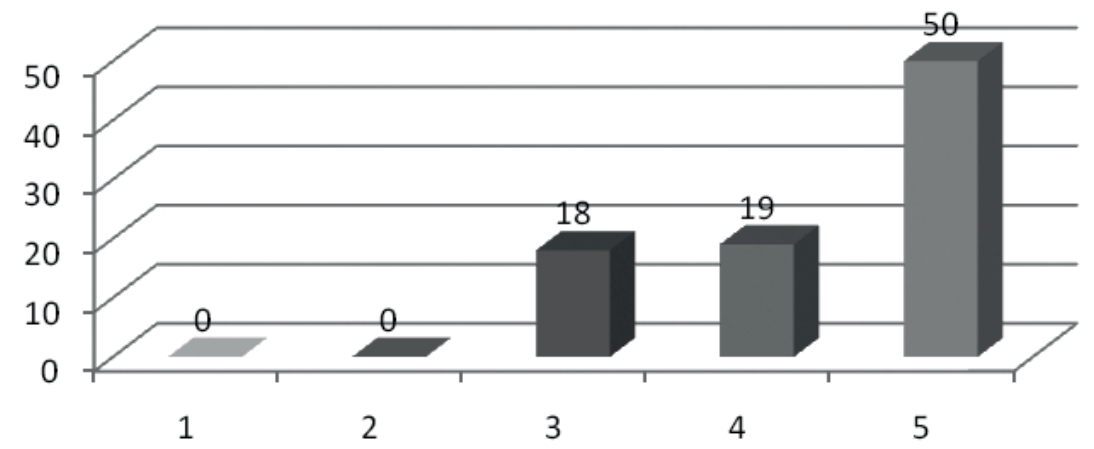

\section{Controlling is the place of planning and business analysis}

In many enterprises in the previous period, there was a planning and analysis department that performed the tasks of planning, analysis, and business improvement. Today's modern companies have transferred this service to the controlling department and introduced controlling as a completely new department. So, what is the difference between planning and analysis and controlling? Controlling uses a much larger number of operational and strategic management tools to perform these tasks than the planning and analysis department. In addition to planning and analysis, controlling also offers recommendations for business improvement for shorter periods of time, i.e. on monthly, 
semi-annual and annual basis, rather than only on annual basis, as it was the case before (Chart 8). In some companies, the results are tracked and reports are submitted to the management on a daily and weekly basis if needed.

Chart 8. Controlling is the place of planning and business analysis

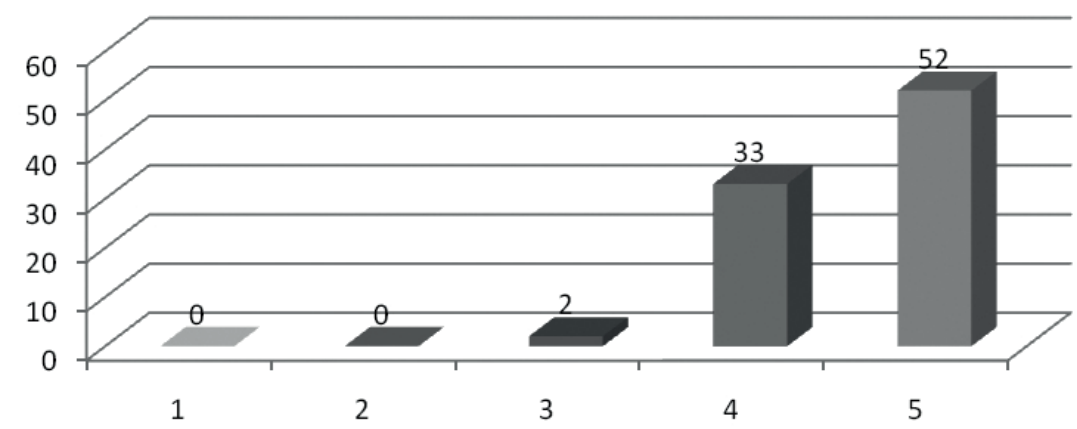

All these functions of controlling were recognized by respondents of this survey, who believed that controlling is the place of planning and analysis, in addition to other tasks assigned to it. As many as 85 respondents agreed or fully agreed with this, while this statement was rated 3 (partially agree) by 2 respondents. Not a single respondent answered that they disagreed with this statement so that it could be assumed that all respondents were aware of controlling as a business function.

\section{Controlling is a consultant for business decisions}

The analysis of this question reflects the core of understanding controlling, while most respondents believed that controlling is the place of planning and analysis, this is not the case with the statement that controlling is a consultant in decision making. This can be explained by the deeply held belief in Serbian companies that it is necessary to make a plan and do the analysis, while decisions should be made by the management alone.

Chart 9. Controlling is a consultant in business decisions

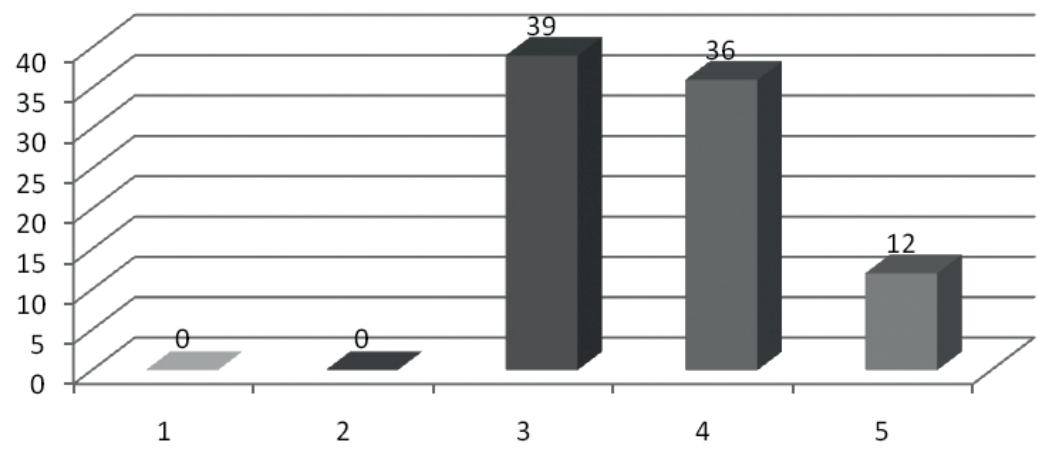

The management is to decide, but the controlling department should actively assist by playing a consultative role, that is, the controller should be the person who plans, analyzes, and controls the business processes and reports to the management. In addition to these tasks, the controller should give suggestions for improving the operation and be a consultant to the management. The respondents failed to answer this question exactly in this way, as only 12 respondents rated this statement with the highest score (5), while 39 , or almost $45 \%$ rated it with 3 , and 36 with 4 (Chart 9). Is controlling in Serbian companies only a report submitted to their headquarters in already prepared forms? Based on this analysis, it can be assumed that in most cases this is true and that controlling has little participation in making some decisions and suggestions.

\section{Controlling is a coordinator and integrator of business functions}

Similar results were obtained as for the previous statement. The explanation is the same because the majority of respondents rated this statement with 3 . However, as many as 9 respondents mainly disagreed with the statement that controlling should be a coordinator and integrator of business functions (Chart 10). 


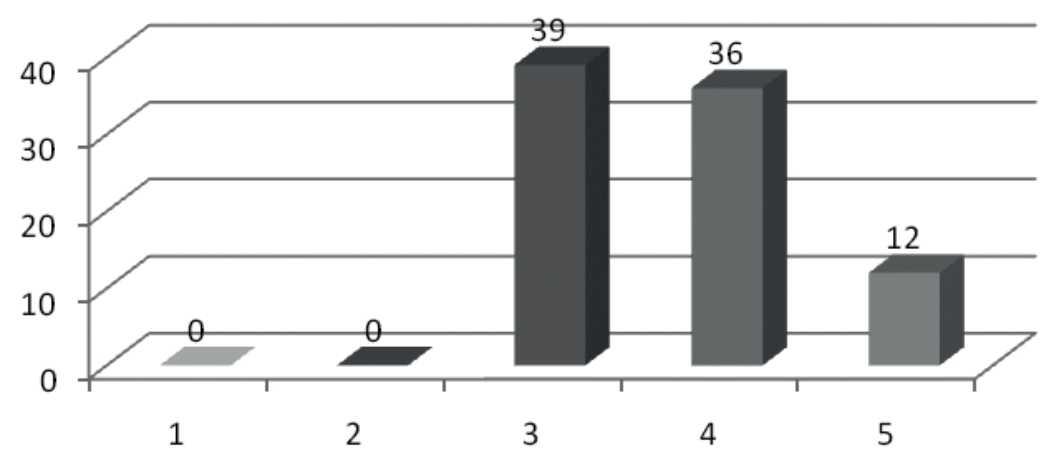

\section{The role of controlling is irrelevant}

Perhaps the most important question in this research was related to the importance of controlling in the enterprise. By analyzing the obtained data, it can be seen that 23 respondents believed that controlling is completely irrelevant to their businesses, 5 respondents also considered it unimportant, while 17 of them agreed with this statement (Chart 11). This is a significant indication, given that 45 respondents (or slightly more than 50\%) believed that they could do business successfully without controlling. Is controlling still in the initial stage of development in the Republic of Serbia? Are we still lacking the quality staff to perform these tasks? Do employees in companies still think that the planning and analysis department is sufficient for their business? The answer to these questions may be assumed to lie just in this analysis, since about $50 \%$ of the respondents believe that they can do business without controlling, which reflects their lack of knowledge about the role of controlling in the company, as well as the lack of adequate experts in this field who would disprove them and demonstrate the contribution of controlling.

Chart 11. The role of controlling is irrelevant

\section{CLOSING CONSIDERATIONS}

Given the recent developments in the field of controlling in terms of theory and practice, the author of this paper believes that there is a need for considering the state of controlling in the Republic of Serbia.

Regarding the presence of controlling in Serbian enterprises, the conclusion is that mainly medium-sized and large companies use controlling in their organizational scheme. The analysis indicated that there is a growing tendency in presence of controlling in the Republic of Serbia: the fact is that $69 \%$ of companies that participated in the study have controlling implemented in their business, but as many as $31 \%$ of companies are in the process of implementation.

There is only one faculty in the Republic of Serbia where controlling has been studied as a scientific discipline. Despite this fact, the level of skills of employees working in controlling departments is acceptable.

One of the conclusions of this research is that controlling has mainly been implemented in subsidiaries of foreign companies (from sectors like mechanical engineering, pharmaceutical, industry, oil industry).

The $69 \%$ share of the analyzed companies in the Republic of Serbia that have introduced controlling in their business 
should encourage companies to intensify introduction of controlling, rather than discourage. This would be facilitated by studying it as a scientific discipline at a higher number of faculties and universities and making both employees and managers familiar with the advantage of introducing controlling in their company.

\section{LITERATURE}

Bojanić, R. (2012). Kontroling u Srbiji -utopija ili realnost. II konferencija kontroling i interna revizija, Novi Sad, 3031.12.2012. godine, str. $12-15$.

Horávth, P. (2009). Das Controlling konzept. Stuttgard.

Osmanagić Bedenik, N. (2007). Realnost kontrolinga u Hrvatskoj-rezultati empirijskog istraživanja. Zbornik Ekonomskog fakulteta u Zagrebu, god. 5, broj 1, Zagreb.
Perović, V. (2016). Uloga i značaj primene kontrolinga u poslovnoj praksi, Računovodstvo. Časopis za računovodstvo, reviziju i poslovne finansije. God. LX, Br. 1-2016, str. 168 - 183.

Perović, V., Bojanić, R. (2016). Osnove kontrolinga. Univerzitet u Novom Sadu - Fakultet tehničkih nauka, Novi Sad str. $31-38$.

Perović, V., Osmanagić-Bedenik, N., Bojanić, R., Todorović-Dudić, A. (2016). Recent Situation of Controlling in Serbia and Comparason with its Implementation in Croatia. Revizor. 2016, No 76/2016, pp. 29 - 39.

Perović, V., Vujičić, M. (2015). Controlling: between theory and practice. International Journal of Industrial Engineering and Management - IJIEM. 2015, Vol. 6, No 4-2015, pp. 165-170.

Todorović-Dudić, A., Stanišić, M., Perović, V. (2017). Contribution of Controlling to business efficiency. Industrija. Vol. 45 , No 1, pp. $22-44$.

Weber, J., Schäffer, U. (2008). Einführung in das Controlling. Stuttgard. 